\title{
DESIGN OF MICROIRRIGATION SYSTEMS IN SLOPING LANDS USING LINEAR PROGRAMMING ${ }^{1}$
}

\author{
João CarlosCury Saad \\ Department of Rural Engineering, College of Agricultural Sciences, São Paulo State University, P.O. \\ 237, CEP 18603-970, Botucatu, SP.E-mail: joaosaad@fca.unesp.br \\ Miguel A. Mariño \\ Department of Land, Air and Water Resources and Department of Civil \& Environmental Engineering, \\ University of California, Davis, CA 95616,USA.E-mail:mamarino@ucdavis.edu
}

\section{SUMMARY}

When the area to be irrigated has a high slope gradient in the manifold line direction, an option is to use a tappered pipeline to reduce pipe costs and keep pressure head variations within desired limits. The purpose of this paper was to develop a linear programming model to design a microirrigation system with tappered manifold lines in downhill condition, minimizing the equivalent annual cost of hydraulic network and the energy annual cost, and assuring that the maximum variation in the pressure head previously established will be observed. The input data are: irrigation system layout, cost of all hydraulic network components and energy cost. The output are: equivalent annual cost, pipeline diameter in each line of the system, pressure head in each node, and total operating pressure head. To illustrate its capability, the model was applied in a citrus orchard in Sao Paulo State, Brazil. The model proved to be efficient in the design of the irrigation system in terms of emission uniformity desired. The pumping annual cost must be considered in the microirrigation system design because it yields a lower total annual cost when compared with the same alternative without that cost.

KEYWORDS: linear programming, optimization, slope land, micro irrigation

\section{SAAD, J. C. C.; MARIÑO, M. A. DIMENSIONAMENTO DE SISTEMAS DE IRRIGAÇÃO POR MICROASPERSÃO EM ÁREAS COM DECLIVIDADE UTILIZANDO PROGRAMAÇÃO LINEAR}

\section{RESUMO}

Quando a área a ser irrigada apresenta um elevado gradiente de declive na direção das linhas de derivação, uma opção de dimensionamento é o uso de tubulações com vários diâmetros para economizar no custo e também para manter a variação de pressão dentro dos limites desejados. O objetivo deste

\footnotetext{
${ }^{1}$ Financial support provided by FAPESP
} 
trabalho foi desenvolver um modelo de programação linear para dimensionar sistemas de irrigação por microaspersão com linhas de derivação com mais de um diâmetro e operando em declive, visando a minimização do custo anualizado da rede hidráulica e do custo anual com energia elétrica, além de assegurar que a máxima variação de carga hidráulica na linha será respeitada. Os dados de entrada são: configuração da rede hidráulica do sistema de irrigação, custo de todos os componentes da rede hidráulica e custo da energia. Os dados de saída são: custo anual total, diâmetro da tubulação em cada linha do sistema, carga hidráulica em cada ponto de derivação e altura manométrica total. Para ilustrar a potencialidade do modelo desenvolvido, ele foi aplicado em um pomar de citros no Estado de São Paulo, Brasil. O modelo demonstrou ser eficiente no dimensionamento do sistema de irrigação quanto à obtenção da uniformidade de emissão desejada. O custo anual com bombeamento deve ser considerado no dimensionamento de sistemas de irrigação por microaspersão porque ele gera menores valores de custo anual total quando comparado com a mesma alternativa que não considera aquele custo.

UNITERMOS: programação linear, otimização, declividade, microaspersão

\section{INTRODUCTION}

Micro irrigation irrigation is a convenient and efficient method of supplying water to the root zone of trees. As a permanent irrigation system, the hydraulic network design greatly influences in the initial equipment cost. Therefore, optimization of the system design is key to maximizing profitability and emission uniformity. These have been the goals of many previously developed procedures.

The trickle irrigation systems are recommended to be used in sloping lands, usually with lateral lines in level, following the row of trees. When the area to be irrigated has a high slope gradient in the manifold line direction, an option is to use a tapered pipeline. This is done to economize on pipe costs and to keep the pressure head variations within the desired limits (KELLER \& BLIESNER, 1990).

The design criterion adopted in trickle irrigation systems defines the allowable pressure variation in the manifold line. It is the maximum allowable difference between the maximum and minimum pressure in the outlets of the line. The location of these extremes pressure points is required to design the manifold line. In downhill lines, the location of the maximum and the minimum pressure heads is variable and depends on the relationship between the total energy gain by slope and the total head losses due the pipe friction. There is an analytical solution for single diameter lines, but in the case of tapered lines, the solution becomes more complex and requires numerical simulation.

Linear programming (LP) models have been used to design permanent irrigation systems (PLEBAN \& AMIR, 1981; ORON \& KARMELI, 1981; ORON \& WALKER, 1981; BENAMI \& OFEN, 1984; SAAD et al., 1993). AS of now, however, a downhill condition for the tapered manifold line has not been considered. The purpose of this paper is: to develop a linear programming model to design a micro irrigation system with tapered manifold lines in the downhill condi-tion, assuring that the maximum established variation in the pressure head will be maintained. To illustrate its capability, the model will be applied to the design of a micro irrigation system for a citrus orchard located in Limeira, Sao Paulo, Brazil.

\section{THE MODEL}

The developed model has the following assumptions: (1) the irrigated area must be rectangular; (2) the slope must be uniform in both directions; (3) the system lay-out and the operation conditions must be previously defined; (4) the lateral lines are in level and they have only one diameter; (5) the pressure in the inlet must be the 
same in all the sub-units; (6) the manifold lines are in the downhill condition.

\subsection{Objective function}

The objective function to be minimized is the equivalent annual cost of the irrigation system.

$$
\begin{gathered}
\mathrm{C}=\left(\mathrm{C}_{\mathrm{e}}+\mathrm{C}_{\mathrm{pe}}+\mathrm{C}_{\mathrm{pvc}} \mathrm{C}_{\mathrm{v}}+\mathrm{C}_{\mathrm{p}}+\mathrm{C}_{\mathrm{cp}}+\right. \\
\left.\mathrm{C}_{\mathrm{f}}\right) \cdot \mathrm{CRF}+\mathrm{C}_{\mathrm{pp}}
\end{gathered}
$$

where $\mathrm{C}$ is the equivalent annual cost of irrigation system in US\$, $\mathrm{C}_{\mathrm{e}}$ is the total cost with emitters in US\$, $\mathrm{C}_{\mathrm{pe}}$ is the polyethylene pipeline cost in US\$, $\mathrm{C}_{\mathrm{pvc}}$ is the polyvinyl chloride (PVC) pipeline cost in US\$, $\mathrm{C}_{\mathrm{V}}$ is the valves cost in US\$, $C_{p}$ is the pump system cost in US\$, $\mathrm{C}_{\mathrm{cp}}$ is the control panel cost in US\$, $\mathrm{C}_{\mathrm{f}}$ is the filter system cost in US\$, CRF is the capital recovery factor and $\mathrm{C}_{\mathrm{pp}}$ is the annual pumping cost in US\$. estimated by:

The objective function components are

$$
\begin{aligned}
& C_{e}=N_{s} N_{1} N_{m} P_{m} \\
& C_{p e}=N_{s} N_{1} L P_{p e} \\
& C_{p v c}=N_{s} \sum_{j=1}^{J} \sum_{i=1}^{1} P_{i} M_{i}+2 \sum_{k=1}^{K} \sum_{r=1}^{R} P_{r} L S_{k, r}+ \\
& \sum_{k=1}^{K} \sum_{v=1}^{v} P_{v}=N_{s} P_{k, v} \\
& C_{p p}=\frac{10.787 Q H I_{d} I_{h} E}{E_{f}}
\end{aligned}
$$

where $\mathrm{N}_{\mathrm{S}}$ is the number of subunits, $\mathrm{N}_{1}$ is the number of lateral lines in the sub- unit, $\mathrm{N}_{\mathrm{m}}$ is the number of micro sprinklers in the lateral line, $\mathrm{P}_{\mathrm{m}}$ is the micro sprinkler price (US\$/unit), $\mathrm{L}$ is the lateral line length in $\mathrm{m}, \mathrm{P}_{\mathrm{pe}}$ is the polyethylene pipe price in US\$ $/ \mathrm{m}, \mathrm{PM}_{\mathrm{i}}$ is the price of the PVC pipe with diameter $\mathrm{i}$ used in the manifold line, in US\$/m, $\mathrm{LM}_{\mathrm{j}, \mathrm{i}}$ is the length, in $\mathrm{m}$, of the $\mathrm{PVC}$ pipeline with diameter $i$ in the section $j$ of the manifold line, $\mathrm{PS}_{\mathrm{r}}$ is the price of the PVC pipe with diameter $r$ used in the sub-main line, in US\$/m, $\mathrm{LS}_{\mathrm{k}, \mathrm{r}}$ is the length, in $\mathrm{m}$, of the PVC pipeline with diameter $\mathrm{r}$ used in the sub-main $\mathrm{k}, \mathrm{PN}_{\mathrm{v}}$ is the price of the PVC pipe with diameter $\mathrm{v}$ used in the main line, in $\mathrm{US} \$ / \mathrm{m}, \mathrm{LN}_{\mathrm{k}, \mathrm{v}}$ is the length, in $\mathrm{m}$, of the PVC pipeline with diameter $\mathrm{v}$ in the section $\mathrm{k}$ of the main line, $\mathrm{P}_{\mathrm{V}}$ is the valve price in US\$/unit, $Q$ is the total discharge in $\mathrm{m}^{3} / \mathrm{s}, \mathrm{I}_{\mathrm{d}}$ is the number of irrigation days during the season, $I_{h}$ number of irrigation hours per set of sub-units working simultaneously, $\mathrm{E}$ is the electricity price in US\$/ $\mathrm{kWh}$, and $\mathrm{E}_{\mathrm{f}}$ is the water application efficiency.

The decision variables are: $\operatorname{LM}_{\mathrm{j}, \mathrm{i}}$, $\mathrm{LS}_{\mathrm{k}, \mathrm{r}}, \mathrm{LN}_{\mathrm{k}, \mathrm{v}}$ and total operating head (HT). The lateral line diameter must be previously defined.

\subsection{Constraints}

\subsubsection{Area}

These constraints are required to insure adherence to the previously defined irrigation system design criteria.

For the section $1(j=1)$ of the manifold line:

$\sum_{\mathrm{i}=1}^{\mathrm{I}} \mathrm{LM}_{1, \mathrm{i}}=0.5 \mathrm{~S}_{\mathrm{L}}$

For sections $\mathrm{j}=2$ to $\mathrm{J}$ of the manifold line: 


$$
\sum_{\mathrm{i}=1}^{\mathrm{I}} \mathrm{LM}_{\mathrm{j}, \mathrm{i}}=\mathrm{S}_{\mathrm{L}}
$$

For the sub-main lines $\mathrm{k}=1$ to $\mathrm{K}$ :

$$
\sum_{\mathrm{r}=1}^{\mathrm{R}} \mathrm{LS}_{\mathrm{k}, \mathrm{r}}=\mathrm{S}_{\mathrm{k}}
$$

For the section $\mathrm{k}=1$ to $\mathrm{K}$ of the main line:

$\sum_{\mathrm{v}=1}^{\mathrm{V}} \mathrm{LN}_{\mathrm{k}, \mathrm{v}}=\mathrm{N}_{\mathrm{k}}$

where $\mathrm{S}_{\mathrm{L}}$ is the spacing between lateral lines in $\mathrm{m}, \mathrm{S}_{\mathrm{k}}$ is the length of the submain line $\mathrm{k}$, in $\mathrm{m}, \mathrm{N}_{\mathrm{k}}$ is the length of the section $\mathrm{k}$ of the main line, in $\mathrm{m}$.

\subsubsection{Hydraulic constraints}

\subsubsection{Manifold design}

The model assumes that the manifold line can have two pressure head profiles. In both, the minimum pressure head is located in a point between the ends of the line. When the relationship between the total energy gain by slope and the total head losses due the pipe friction is less than 1 and larger than 0 , the maximum pressure head will be at the inlet (Figure 1). When this relationship is equal to 1, the maximum pressure will be at the inlet and in the last outlet (Figure 2).

\section{HMo $\quad$ Manifold line $\rightarrow$ flow direction}

Pressure profile

HMo $=$ inlet pressure

Figure 1. Profile I: the relationship between the total energy gain by slopes and the total head losses due to pipe friction is less than 1 and larger than 0 .

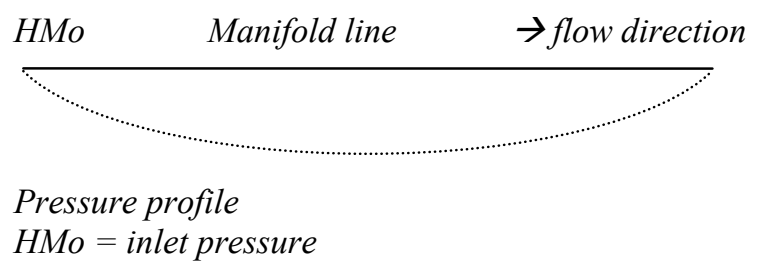

Figure 2. Profile II; the relationship between the total energy gain by slopes and the total head losses due to pipe friction is equal to 1 .

These profiles are represented by the set of equations:

For $\mathrm{j}=1, \ldots, \mathrm{J}$ :

$\mathrm{HM}_{\mathrm{o}}-\mathrm{HM}_{\mathrm{j}} \geq 0$

For $\mathrm{j}=1, \ldots, \mathrm{J}$ :

$\mathrm{HM}_{\mathrm{o}}-\mathrm{HM}_{\mathrm{j}} \leq \mathrm{DM}$

where $\mathrm{HM}_{\mathrm{O}}$ is the pressure head at the inlet of the manifold line in $\mathrm{m}, \mathrm{HM}_{\mathrm{j}}$ is the pressure head at the outlet $j$ of the manifold line, in $\mathrm{m}$, and $\mathrm{DM}$ is the maximum value of the head loss allowed in the manifold line, in $\mathrm{m}$.

The eq. 11 assures that no outlet will have pressure higher than the inlet pressure. The pressure difference between the inlet and any outlet must be less than or equal to the maximum value of the head loss allowed in the manifold line (DM) to assure the desired emission uniformity (equation 12).

In a tapered manifold line it is impossible to know previously which outlet will have the lowest pressure. The equation 11 assures that the difference of pressure head between the maximum and any manifold outlet will be lower than DM. So, this set of constraints insure that the difference between the maximum and the minimum pressure will be less or equal DM, independent of the location of the minimum pressure.

The average pressure head in the manifold line must be equal to the inlet 
pressure head in the lateral line where is located the micro sprinkler working pressure.

$\mathrm{H}_{\mathrm{av}}=\mathrm{h}_{\mathrm{w}}+0.75 \mathrm{hf}_{1}$

$\mathrm{H}_{\mathrm{av}}=\frac{\left(\sum_{\mathrm{j}=1}^{\mathrm{J}} \mathrm{HM}_{\mathrm{j}}\right)}{\left(\frac{\mathrm{N}_{\mathrm{l}}}{2}\right)}$

where $\mathrm{H}_{\mathrm{av}}$ is the average pressure in the manifold line, in $\mathrm{m}, \mathrm{h}_{\mathrm{w}}$ is the micro sprinkler working pressure, in $\mathrm{m}$, and $\mathrm{hf}_{1}$ is the pressure head loss in the lateral line in $\mathrm{m}$.

\subsubsection{Pressure head at the manifold outlets}

The pressure at the sub-unit inlet, before the valve, is given by:

$$
\begin{aligned}
\mathrm{H}_{\mathrm{u} 0}= & 0.75 \mathrm{hf}_{1}+\mathrm{h}_{\mathrm{w}}+\mathrm{H}_{\mathrm{v}}+ \\
& 1.050 .63 \sum_{\mathrm{i}=1}^{\mathrm{L}} \mathrm{JM}_{\mathrm{j}, \mathrm{i}} \mathrm{LM}_{\mathrm{j}, \mathrm{i}}+0.5 \mathrm{M} \mathrm{dz}
\end{aligned}
$$

where $\mathrm{H}_{\mathrm{uo}}$ is the pressure at the subunit inlet in $\mathrm{m}, \mathrm{H}_{\mathrm{v}}$ is the head loss in the valve in $\mathrm{m}, \mathrm{JM}_{\mathrm{i}, \mathrm{j}}$ is the unitary head loss, in $\mathrm{m} / \mathrm{m}$, in the PVC pipe with diameter $i$ used in the section $j$ of the manifold line, $M$ is the manifold line length in $\mathrm{m}$, and $\mathrm{dz}$ is the slope gradient in $\mathrm{m} / \mathrm{m}$.

The manifold inlet pressure $\left(\mathrm{HM}_{\mathrm{o}}\right)$, located after the valve, is given by:

$\mathrm{HM}_{\mathrm{o}}=\mathrm{H}_{\mathrm{uo}}-\mathrm{H}_{\mathrm{v}}$

The pressures at the manifold outlets are calculated by:

For $\mathrm{j}=1$ :

$$
\begin{aligned}
\mathrm{HM}_{1}= & \mathrm{HM}_{0}-1.05 \sum_{\mathrm{i}=1}^{\mathrm{I}} \mathrm{JM}_{1, \mathrm{i}} \mathrm{LM}_{1, \mathrm{i}}+ \\
& 0.5 \mathrm{~S}_{\mathrm{L}} \mathrm{dz} \\
\text { For } \mathrm{j}= & 1 \text { to } \mathrm{J}: \\
\mathrm{HM}_{\mathrm{j}}= & \mathrm{HM}_{\mathrm{j}-1}-1.05 \sum_{\mathrm{i}=1}^{\mathrm{I}} \mathrm{JM}_{\mathrm{j}, \mathrm{i}} \mathrm{LM}_{\mathrm{j}, \mathrm{i}}+ \\
& \mathrm{S}_{\mathrm{L}} \mathrm{dz}
\end{aligned}
$$

The total head loss in the manifold line $\left(\mathrm{hf}_{\mathrm{d}}\right)$, in $\mathrm{m}$, is given by:

$\mathrm{hf}_{\mathrm{d}}=1.05 \sum_{\mathrm{i}=1}^{\mathrm{I}} \mathrm{JM}_{\mathrm{j} . \mathrm{i}} \mathrm{LM}_{\mathrm{j}, \mathrm{i}}$

The factor 1.05 in the equations 15,17 , 18 and 19 is used to estimate the localized head losses.

\subsubsection{Pressure head at the main line outlets}

The pressures at the main line inlet and in each outlet are estimated by:

$$
\mathrm{H}_{\mathrm{o}}=\mathrm{HT}-\mathrm{H}_{\mathrm{cs}}-\mathrm{H}_{\mathrm{su}}
$$

For $\mathrm{k}=1$ to $\mathrm{K}$ :

$$
\mathrm{H}_{\mathrm{k}}=\mathrm{H}_{\mathrm{k}-1}-\mathrm{Ndz}-1.05 \sum_{\mathrm{v}=1}^{\mathrm{v}} \mathrm{JN}_{\mathrm{k}, \mathrm{v}} \mathrm{LM}_{\mathrm{k}, \mathrm{v}}
$$

where $\mathrm{H}_{\mathrm{O}}$ is the pressure at the main line inlet in $\mathrm{m}, \mathrm{H}_{\mathrm{cs}}$ is the head loss in the control station in $\mathrm{m}, \mathrm{H}_{\mathrm{su}}$ is the suction lift in $\mathrm{m}, \mathrm{H}_{\mathrm{k}}$ is the pressure at the outlet $\mathrm{k}$ of the main line in $\mathrm{m}, J \mathrm{~N}_{\mathrm{k}, \mathrm{v}}$ is the unit head loss, in $\mathrm{m} / \mathrm{m}$, in the pipe with diameter $\mathrm{v}$ used in the section $\mathrm{k}$ of the main line.

4.2.2.4 Design of the sub-main lines 
The sub main lines are designed as a function of the required pressure at the subunit inlet and the pressure available in the main line outlet.

For $\mathrm{k}=1$ to $\mathrm{K}$ :

$$
1.05 \sum_{\mathrm{r}=1}^{\mathrm{R}} \mathrm{JS}_{\mathrm{k}, \mathrm{r}} \mathrm{LS}_{\mathrm{k}, \mathrm{r}} \geq \mathrm{H}_{\mathrm{k}}-\mathrm{H}_{\text {uо }}
$$

where $\mathrm{JS}_{\mathrm{k}, \mathrm{r}}$ is the unit head loss, in $\mathrm{m} / \mathrm{m}$, in the PVC pipe with diameter $r$ used in the sub main line $\mathrm{k}$.

\subsubsection{Total operating head}

The total operating head (HT), in m, is equal to the total pressure required to operate the sub-unit under the most critical condition. The model assumes that the water distribution is accounted for from the pump station to the sub-unit under uphill conditions. So, the most critical condition will be at the farthest sub-unit.

$$
\begin{gathered}
\mathrm{HT}=\mathrm{H}_{\text {ио }}+1.05 \sum_{\mathrm{k}=1}^{\mathrm{K}} \sum_{\mathrm{v}=1}^{\mathrm{v}} \mathrm{JN}_{\mathrm{k}, \mathrm{v}} \mathrm{LN}_{\mathrm{k}, \mathrm{v}}+ \\
\mathrm{K} \mathrm{dz} \mathrm{N}+\mathrm{H}_{\mathrm{cs}}+\mathrm{H}_{\mathrm{su}}
\end{gathered}
$$

\subsection{Software}

The optimization model was solved using the Gams package (BROOKS et al., 1988), based in the Simplex Method.

\section{APPLICATION OF THE MODEL}

\subsection{Lay-out}

To illustrate the capability of the model, it was used to design a micro irrigation system for_a citrus orchard, in the state of Sao Paulo, Brazil. The area is $600 \mathrm{~m}$ by $400 \mathrm{~m}$, with $4.5 \%$ of slope in the lower length direction.

The design criterion was based in the emission uniformity (EU). For a EU value of $90 \%$, the allowable head loss in the sub-unit is $4.8 \mathrm{~m}$. This value was equally divided between lateral and manifold lines.

The lateral line was design with only one diameter $(13 \mathrm{~mm})$. Its length was obtained from the allowable head loss, using the DarcyWeisbach equation associated with the friction factor equation proposed by Churchill (1977). This procedure can be found in Scaloppi \& Allen (1993). As result, the lateral line length is $46 \mathrm{~m}$ on each side of the manifold line. The area was divided in 24 sub-units, with manifold lines of $94.5 \mathrm{~m}$. The first lateral line is $3.5 \mathrm{~m}$ from the manifold inlet. The regular spacing between the other lateral lines in the manifold is $7 \mathrm{~m}$. So, there are 14 sections in the manifold line $(j=1$ to 14$)$.

Figure 3 shows the hydraulic network layout with the 24 sub-units. For each irrigation cycle, four sub-units work simultaneously (one per sub-main line k). The trees are planted on lines of equal elevation. The micro sprinkler discharge is $43 \mathrm{~L} / \mathrm{h}$ at a working pressure of $15.5 \mathrm{~m}$. There are four pairs of sub-main lines $(\mathrm{k}=1$ to 4$)$, each one connected to the main line outlet of same number $\mathrm{k}$, and there are four sections in the main line ( $k=1$ to 4$)$. The first section is at the control station and it extends to the first outlet (sub-main $\mathrm{k}=1$ ), with discharge $\mathrm{Q}$ (equivalent to 4 sub-units). The second section is located between the first and the second outlet and discharges $3 / 4$ of $Q$ (equivalent to 3 sub-units). The third and fourth sections follow the same logic.

The model was applied with and without consideration of the annual pumping cost to analyze the effect of the electricity price in the irrigation system design. 
$600 \mathrm{~m}$

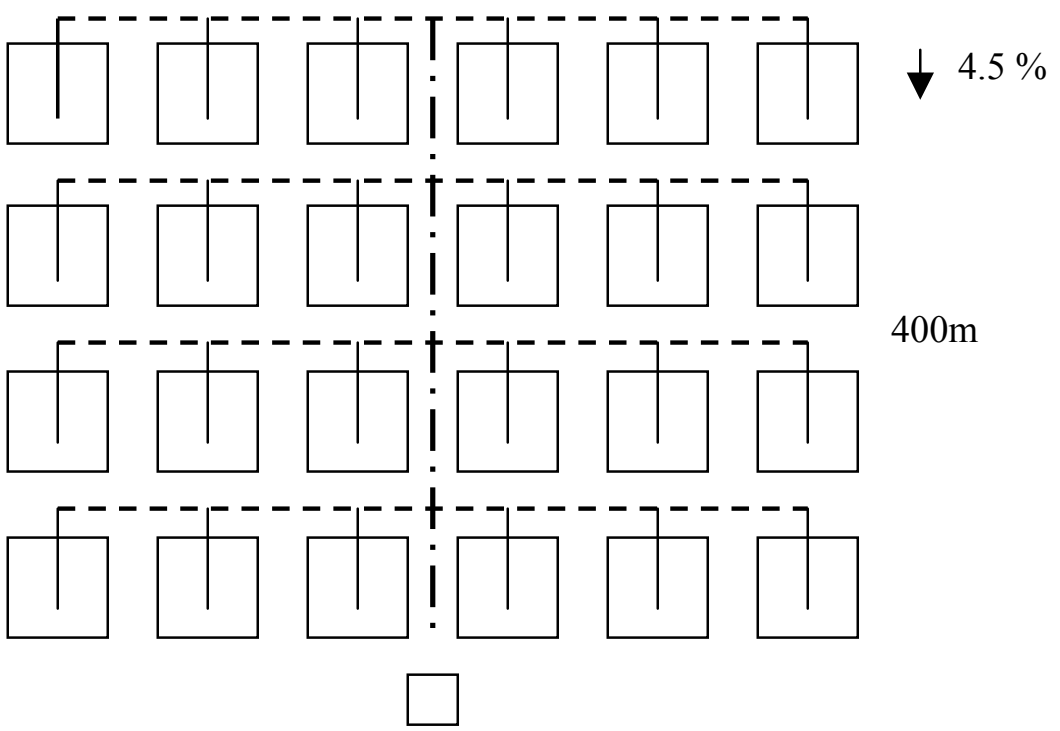

valve

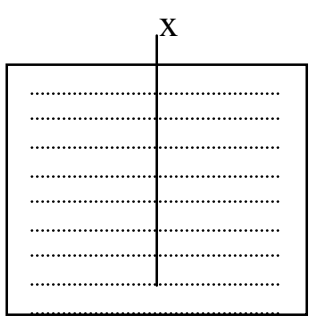

Sub-unit

Control station

Lateral line

Manifold line

- - -. Sub-main line

- - Main line

Figure 3. Irrigation system layout with the 24 sub-units.

5.2 Input data

In this design, the PVC pipes have two pressures rating: $40 \mathrm{~m}$ and $80 \mathrm{~m}$. In the $40 \mathrm{~m}$ class, the nominal diameters are: $35,50,75$, 100,125 and 150 . In the 80 class, the values were: 75,100 and 150 . The pipe prices in function of diameter and pressure class are in Table 1.

The input data are showed in the Table 2 They describe the hydraulic and operational conditions, the equipment prices, the design criterion and the irrigated area dimensions.

The manifold line has pipe $40 \mathrm{~m}$ class. The pressure classes used in the sub-main and main lines are shown in Table 3.

The pressure head losses are a function of the discharge, pipe diameter and pressure class and are shown in Table 4 for the manifold line and in Table 5 for the sub-main and main lines.

Table 1. Prices of the PVC pipes in function of diameter and pressure rating.

\begin{tabular}{ccc}
\hline $\begin{array}{c}\text { Pressure } \\
\text { class }\end{array}$ & $\begin{array}{c}\text { Nominal } \\
\text { diameter (ND) }\end{array}$ & $\begin{array}{c}\text { Price } \\
(\mathrm{US} \$ / \mathrm{m})\end{array}$ \\
\hline \multirow{4}{*}{$40 \mathrm{~m}$} & 35 & 0.54 \\
& 50 & 0.75 \\
& 75 & 1.44 \\
& 100 & 2.31 \\
& 125 & 3.78 \\
$80 \mathrm{~m}$ & 150 & 5.37 \\
\hline & 75 & 2.14 \\
& 100 & 4.23 \\
& 150 & 8.45 \\
\hline
\end{tabular}


Table 2. Values of the input parameters.

\begin{tabular}{|c|c|}
\hline Parameters & \\
\hline number of sub-units $-\mathrm{N}_{\mathrm{S}}$ & 24 \\
\hline $\begin{array}{l}\text { number of lateral lines in the sub-unit }\left(\mathrm{N}_{1}\right) \text {, considering both sides of the } \\
\text { manifold. }\end{array}$ & 28 \\
\hline Spacing between lateral lines $\left(\mathrm{S}_{\mathrm{L}}\right)$, in $\mathrm{m}$ & 7 \\
\hline Spacing between micro sprinklers in the lateral line, in $\mathrm{m}$ & 4 \\
\hline Length of the lateral line $(\mathrm{L})$, in $\mathrm{m}$ & 46 \\
\hline Length of the manifold line $(\mathrm{M})$, in $\mathrm{m}$ & 94.5 \\
\hline number of micro sprinkler in the lateral line $-\mathrm{N}_{\mathrm{m}}$ & 12 \\
\hline $\begin{array}{l}\text { Length of the sub-main line }\left(S_{k}\right) \text {, in } m \text {. In this case, the same for all values of } \\
k(k=1 \text { to } 4) \text {. }\end{array}$ & 250 \\
\hline $\begin{array}{l}\text { Length of the main line }\left(\mathrm{N}_{\mathrm{k}}\right) \text {, in } \mathrm{m} \text {. In this case, the same for all sections } \mathrm{k}(\mathrm{k} \\
=1 \text { to } 4) \text {. }\end{array}$ & 98 \\
\hline Slope gradient $(\mathrm{dz})$, in $\mathrm{m} / \mathrm{m}$ & 0.045 \\
\hline Micro sprinkler price $\left(\mathrm{C}_{\mathrm{m}}\right)$, in US\$/unit & 0.59 \\
\hline Polyethylene pipe price with $13 \mathrm{~mm}$ diameter $\left(\mathrm{C}_{1}\right)$, in US\$/m & 0.13 \\
\hline Electricity price (E), in US\$/kWh & 0.0476 \\
\hline Control panel price $(\mathrm{CCP})$ for 24 sub-units, in US\$ & 1,094 \\
\hline Filter system cost $-\mathrm{C}_{\mathrm{f}}$, in US\$ & 7,055 \\
\hline Valve price $-\mathrm{VV}$, in US\$ & 272.2 \\
\hline Head loss in the lateral line $\left(\mathrm{hf}_{1}\right)$, in $\mathrm{m}$ & 2.4 \\
\hline Head losses in the control station $\left(\mathrm{H}_{\mathrm{cs}}\right)$, in $\mathrm{m}$ & 12 \\
\hline Suction lift $\left(\mathrm{H}_{\mathrm{su}}\right)$, in $\mathrm{m}$ & 3 \\
\hline Head losses in the valves $\left(\mathrm{H}_{\mathrm{v}}\right)$, in $\mathrm{m}$ & 2 \\
\hline Micro sprinkler working pressure $\left(\mathrm{h}_{\mathrm{w}}\right)$, in $\mathrm{m}$ & 15.5 \\
\hline Number of irrigation days during the season $\left(I_{d}\right)$, in days & 120 \\
\hline Number of irrigation hours per set of sub-units working simultaneously $\left(\mathrm{I}_{\mathrm{h}}\right)$ & 18 \\
\hline Number of sub-units working simultaneously & 4 \\
\hline Pump system efficiency - Ef & 0.616 \\
\hline $\begin{array}{l}\text { Capital recovery factor (CRF), for a discount rate of } 6 \% \text { and an irrigation } \\
\text { system life cycle of } 10 \text { years. }\end{array}$ & 0.13587 \\
\hline Allowable head losses in the manifold line - DM, in $\mathrm{m}$ & 2.4 \\
\hline Emission uniformity (EU) & $90 \%$ \\
\hline Total discharge (Q), in $\mathrm{m}^{3} / \mathrm{s}$, to supply 4 sub-units simultaneously & 0.01605 \\
\hline
\end{tabular}

Table 3. Pressure classes in the sub-main and main lines.

\begin{tabular}{ccc}
\hline Line & $\mathrm{K}$ & Pressure class (PC) \\
\hline \multirow{2}{*}{ Sub-main } & 1 & $80 \mathrm{~m}$ \\
& $2,3,4$ & $40 \mathrm{~m}$ \\
\hline \multirow{2}{*}{ Main } & 1,2 & $80 \mathrm{~m}$ \\
& 3,4 & $40 \mathrm{~m}$ \\
\hline
\end{tabular}


Table 4. Head loss, in $\mathrm{m} / \mathrm{m}$, in the manifold line sections in function of pipe diameter and discharge.

\begin{tabular}{cccccc}
\hline \multirow{2}{*}{ Section (j) } & \multicolumn{5}{c}{ Nominal diameter (ND) } \\
\cline { 2 - 6 } 1 & 35 & 50 & 75 & 100 & 125 \\
\cline { 2 - 6 } 2 & - & 0.09832 & 0.01348 & 0.00318 & 0.00118 \\
3 & - & 0.08575 & 0.01179 & 0.00278 & 0.00103 \\
4 & - & 0.0740 & 0.01020 & 0.00241 & 0.00089 \\
5 & - & 0.06307 & 0.00871 & 0.00207 & 0.00077 \\
6 & - & 0.05297 & 0.00734 & 0.00174 & 0.00065 \\
7 & - & 0.04369 & 0.00607 & 0.00144 & 0.00053 \\
8 & - & 0.03525 & 0.00492 & 0.00117 & 0.00044 \\
9 & 0.1198 & 0.02767 & 0.00387 & 0.00093 & - \\
10 & 0.0932 & 0.02094 & 0.00294 & 0.00071 & - \\
11 & 0.06476 & 0.01508 & 0.00213 & - & - \\
12 & 0.04320 & 0.01011 & 0.00144 & - & - \\
13 & 0.02573 & 0.00606 & 0.00087 & - & - \\
14 & 0.01248 & 0.00296 & - & - & - \\
\hline
\end{tabular}

Table 5. Head loss, in $\mathrm{m} / \mathrm{m}$, in the main and sub-main lines in function of the diameter/pressure class and discharge.

\begin{tabular}{ccc}
\hline Pipeline & Nominal diameter (ND) & Head loss $(\mathrm{m} / \mathrm{m})$ \\
\hline Sub-main 1 & 75 & 0.01544 \\
Discharge $=\mathrm{d}$ & 100 & 0.001276 \\
& 150 & 0.000286 \\
\hline \multirow{2}{*}{ Sub-main 2, 3, 4 and Main 4 } & 75 & 0.01348 \\
Discharge = d & 100 & 0.00318 \\
& 125 & 0.00118 \\
Main 3 & 150 & 0.00049 \\
\hline Discharge $=$ 2d & 75 & 0.04792 \\
& 100 & 0.01114 \\
Main 2 & 125 & 0.00409 \\
Discharge $=3 \mathrm{~d}$ & 150 & 0.0017 \\
\hline Main 1 & 75 & 0.1168 \\
Discharge $=4 \mathrm{~d}$ & 100 & 0.009275 \\
& 150 & 0.002044 \\
\hline
\end{tabular}

$\mathrm{d}=$ discharge of one sub-unit

The pump cost $\left(\mathrm{C}_{\mathrm{p}}\right)$, in US\$, is given by:

$\mathrm{C}_{\mathrm{p}}=7.764(\mathrm{HT})+1605.8$

For $50 \leq \mathrm{HT} \leq 80 \mathrm{mca}$
The relationship between the pressure head and the discharge in the micro sprinkler is given by:

$$
q=9.8918 h^{0.5326}
$$

where $\mathrm{q}$ is the micro sprinkler discharge, in $L / h$, for the pressure $h$ in $m$. 


\section{RESULTS AND DISCUSSION}

The model was developed for sloped lands with the manifold line placed in the downhill direction. The design constraints should assure that the difference between the pressure head at any outlet and the inlet pressure head (highest value) would be less than the value (DM), established by the desired emission uniformity. In both situations analysed, with and without consideration of the annual pumping cost, the model was effective for desired purpose, as can be seen in the Figures 4 and 5.

Considering the electricity price, the model designed the manifold line to have two diameters: the first section with $60.7 \mathrm{~m}$ using ND50 (PC40) pipes and the second section $33.8 \mathrm{~m}$ using ND35/PC40. Figure 4 shows the modification in the pressure head profile due to the change in pipe diameter. The manifold inlet pressure head is equal to $17.9 \mathrm{~m}$ and the allowable pressure variation (DM) is $2.4 \mathrm{~m}$. This value was never exceeded. The minimum pressure of $16.9 \mathrm{~m}$ occurs at outlet number 6 (at $38.5 \mathrm{~m}$ from the manifold inlet). The inlet pressure $\left(\mathrm{HM}_{\mathrm{O}}\right)$ and the last outlet $\left(\mathrm{HM}_{14}\right)$ have the same pressure value of $17.9 \mathrm{~m}$, indicating that the relationship between the total energy gain by slopes and the total head losses due to pipe friction is equal to 1 (Pressure profile II).

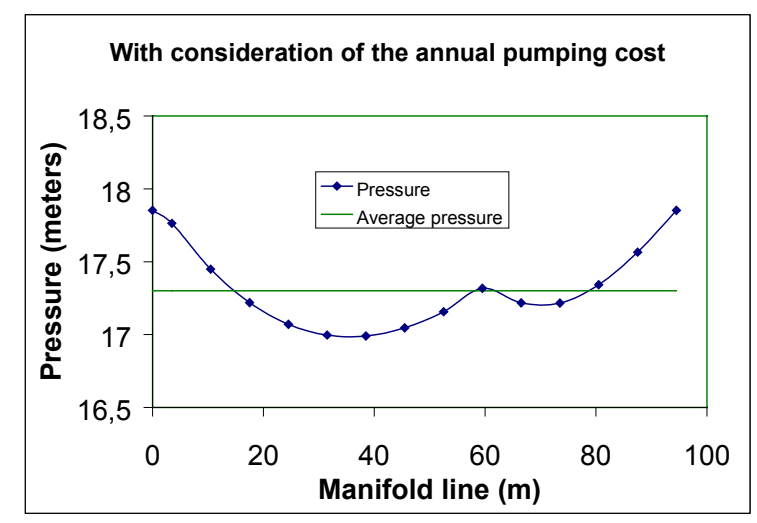

Figure 4. Pressure head profile in the manifold line, considering the energy cost.

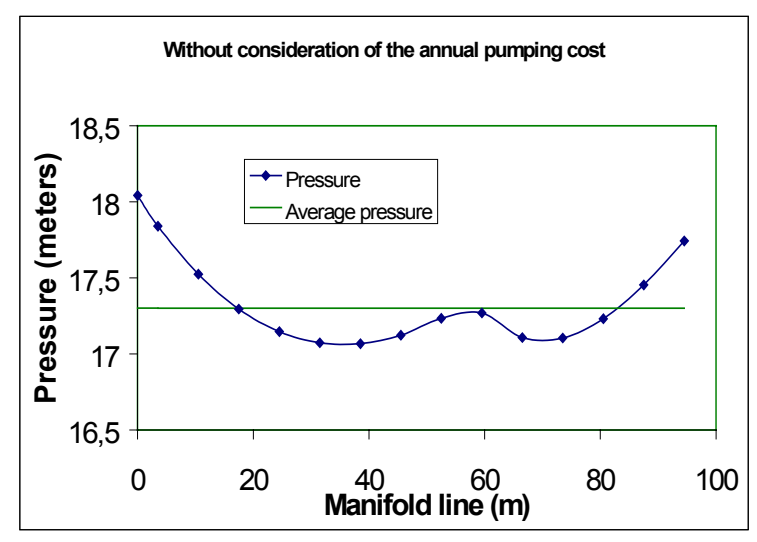

Figure 5. Pressure head profile in the manifold line, non-considering the energy cost.

When the electricity price was not considered, the manifold line designed by the model had two diameters: the first section with $57.8 \mathrm{~m}$ and using ND50 (PC40) pipe and the second section with $31.7 \mathrm{~m}$ using ND35/PC40. Figure 4 shows the modification in the pressure head profile due to the change in pipe diameter. The manifold inlet pressure head is equal to $36.7 \mathrm{~m}$ and the allowable variation (DM) is $2.4 \mathrm{~m}$. This value was never exceeded. The minimum pressure is $17.1 \mathrm{~m}$ and it occurs at the outlet number 6 (at $38.5 \mathrm{~m}$ from the manifold inlet). The inlet pressure $\left(\mathrm{HM}_{\mathrm{O}}=18 \mathrm{~m}\right)$ is higher than the pressure in the last outlet $\left(\mathrm{HM}_{14}=17.7 \mathrm{~m}\right)$, indicating that relationship between the total energy gain by slopes and the total head losses due to pipe friction is less than 1 and larger than 0 (Pressure profile type I).

In both situations, the model was able to design the hydraulic network of the micro irrigation system with tapered manifold line in downhill direction, assuring that the allowable pressure variation, defined by previously established emission uniformity was not exceeded.

Table 6 shows the results with and without consideration of the pumping annual cost. The difference between the two situations is restricted to the annual pumping cost $\left(\mathrm{C}_{\mathrm{pp}}\right)$, pump system cost $\left(\mathrm{C}_{\mathrm{p}}\right)$ and $\mathrm{PVC}$ pipeline cost $\left(\mathrm{C}_{\mathrm{pvc}}\right)$. Without considering the electricity 
cost, the optimisation process selects smaller diameters for all the PVC pipeline, resulting in a less expensive pipeline. Otherwise, the total operating head increases and, consequently, the annual pumping cost and the pump system costs are higher. When the pumping annual cost is considered, the optimisation process makes the choice considering the balance between pipe cost and the associated head losses. In this case, it is better to use larger diameters in the almost all PVC pipeline, because the increase in its annual cost is smaller than the reduction in the pumping annual cost and in the pump system cost.

Although the difference between the two situations analysed, in terms of the equivalent annual cost, is $2 \%$, it is important to realize that the annual pumping cost affects the design of the microirrigation system. It will be more import with increasing total operating head.

Table 6. Output of the linear programming model for optimisation of microirrigation systems, considering and non-considering the energy cost.

\begin{tabular}{|c|c|c|}
\hline Item & Considering energy cost & Without energy cost \\
\hline Number of subunits & 24 & 24 \\
\hline $\begin{array}{l}\text { Number of subunits } \\
\text { working } \\
\text { simultaneously }\end{array}$ & 4 & 4 \\
\hline Lateral line & $46 \mathrm{~m}$ and $13 \mathrm{~mm}$ of diameter & $46 \mathrm{~m}$ and $13 \mathrm{~mm}$ of diameter \\
\hline Manifold line & $\begin{array}{l}60.7 \mathrm{~m} \text { ND50 } \\
33.8 \mathrm{~m} \text { ND35 } \\
\end{array}$ & $\begin{array}{l}57.8 \mathrm{~m} \text { ND50 } \\
36.7 \mathrm{~m} \text { ND35 } \\
\end{array}$ \\
\hline $\begin{array}{c}\text { Sub-main lines } \\
\text { Section } 1 \\
\text { Section } 2 \\
\text { Section } 3 \\
\text { Section } 4 \\
\end{array}$ & $\begin{array}{c}120.6 \mathrm{~m} \text { ND50 / } 129.4 \mathrm{~m} \text { ND75 } \\
85.2 \mathrm{~m} \text { ND50/164.8m ND75 } \\
22.8 \mathrm{~m} \text { ND50/227.2m ND75 } \\
\text { 250m ND100 }\end{array}$ & $\begin{array}{c}206.2 \mathrm{~m} \text { ND50 / 43.8m ND75 } \\
184.3 \mathrm{~m} \text { ND50 / 65.7m ND75 } \\
121.9 \mathrm{~m} \text { ND50 / } 128.1 \mathrm{~m} \text { ND75 } \\
56.9 \mathrm{~m} \text { ND50 / } 193.1 \mathrm{~m} \text { ND75 }\end{array}$ \\
\hline $\begin{array}{l}\text { Main line } \\
\text { Section } 1 \\
\text { Section } 2 \\
\text { Section } 3 \\
\text { Section } 4\end{array}$ & $\begin{array}{l}\text { 98m ND100 (PC80) } \\
98 \mathrm{~m} \text { ND100 (PC80) } \\
\text { 98m ND100 (PC40) } \\
\text { 98m ND100 (PC40) }\end{array}$ & $\begin{array}{c}\text { 98m ND100 (PC80) } \\
\text { 98m ND75 (PC80) } \\
\text { 98m ND100 (PC40) } \\
\text { 98m ND75 (PC40) }\end{array}$ \\
\hline $\begin{array}{c}\text { Total operating head } \\
\text { (HT) }\end{array}$ & $57.4 \mathrm{~m}$ & $66.4 \mathrm{~m}$ \\
\hline $\mathrm{H}_{\mathrm{uo}}$ & $19.9 \mathrm{~m}$ & $20.0 \mathrm{~m}$ \\
\hline $\mathrm{hf}_{\mathrm{d}}$ & $4.3 \mathrm{~m}$ & $4.6 \mathrm{~m}$ \\
\hline $\mathrm{H}_{\mathrm{av}}$ & $17.3 \mathrm{~m}$ & $17.3 \mathrm{~m}$ \\
\hline $\begin{array}{l}\text { Pumping annual cost } \\
\text { (US\$/ha.yr) }\end{array}$ & 69.1 & 80.0 \\
\hline $\begin{array}{c}\text { Pump system cost, } \\
\text { US\$/ha.yr }\end{array}$ & 11.6 & 12.0 \\
\hline $\begin{array}{l}\text { Pvc pipeline cost } \\
\text { (US\$/ha.yr) }\end{array}$ & 34.4 & 28.3 \\
\hline Annual cost (US\$/ha) & 247.9 & 253.1 \\
\hline
\end{tabular}

* ND: nominal diameter; $\mathrm{PC}=$ pressure class 


\section{CONCLUSIONS}

The linear programming model developed was effective in designing the micro irrigation system with tapered manifold lines on downhill slopes, assuring the allowed pressure variation defined by the emission uniformity previously selected.

The pumping annual cost affected the hydraulic design and must be considered in the optimization models. When the electricity cost was considered, the model predicted a lower total annual cost when compared with the same alternative without that factor.

\section{ACKNOWLEDGEMENTS}

The authors are grateful for financial support provided by Fundação de Amparo à Pesquisa do Estado de São Paulo (FAPESP), from Brazil.

\section{REFERENCES}

BENAMI, A.; OFEN, A. Irrigation engineering. Haifa: Irrigation Engineering Scientific Publications, 1984. 257 p.
BROOKS, A.; KENDRICK, D.; MEERAUS, A. GAMS: a user's guide. Redwood City: The Scientific Press, 1988. 289 p.

CHURCHILL, S.W. Friction-factor equation spans all fluid-flow regimes. Chemical Engineering, New York, v. 84, n. 24, p. 91-92, 1977.

KELLER, J.; BLIESNER, R.D. Sprinkle and trickle irrigation. New York: AVI Book, 1990. $652 \mathrm{p}$.

ORON, G.; KARMELI, D. Solid set irrigation system design using linear programming.

Water Resources Bulletin, Urbânia, v. 17, n. 4, p. 565 - 570, 1981.

ORON, G.; WALKER, W.R. Optimal design and operation of permanent irrigation systems.

Water Resources Research, Urbânia, v. 17, n.1, p. $11-17,1981$.

PLEBAN, S.; AMIR, I. An interactive computerized aid for the design of branching irrigating networks. Transactions of the American Society of Agricultural Engineers, Urbânia, v. 24, n.2, p. 358 - 361, 1981.

SAAD, J.C.C. et al. Hydraulic optimization of a drip irrigation system using linear programming. Pesquisa Agropecuária Brasileira, Brasília, v. 29, n.5, p. 797 - 805, 1994.

SCALOPPI, E.J.; ALLEN, R.G. Hydraulics of center-pivot laterals. Journal of Irrigation and Drainage Engineering. v. 119, n.3, p. 554 567, 1993. 